\section{VISUAL AIDS IN ADULT EDUCATION}

\section{ROYAL ARMY EDUCATIONAL CORPS EXHIBITION}

\section{BY Colonel J. T. BURGESS}

$\mathrm{T}$ EACHERS have for many years been counselled to make full use of illustrative material in their teaching; to appeal to the eye as well as to the ear; to vary the approach to their subjects; in fact, to stimulate interest and promote understanding by every means at their disposal. That the Army does not intend to lose the ground in this connexion gained under the impetus of war-time necessity was amply demonstrated at an exhibition of teaching aids held on September 15 at the Army School of Education, Eltham Palace, itself a most appropriate setting for an exhibition of this kind.

The extent to which the Army makes use of the film for training purposes is probably well known, but it may not be so widely appreciated that Army education is making use of the film and the film strip on an increasing scale. Two examples of films in use were shown to visitors, one on Palestine acquired to assist in teaching the men something of the background of the countries in which they may one day find themselves, and the other on teaching method for the training of instructors. On view, too, were some of the 189 film strips made by the Directorate of Army Education covering a wide range of subjects. The Army's agent for film and film strip work is the Army Kinema Corporation, which provides cinematograph entertainment throughout the Army and supplies mobile projectors for training and education purposes to the smaller units not equipped with their own $16-\mathrm{mm}$. projectors. There was an impressive array of the various types of standard equipment used by the Army Kinema Corporation and, what was perhaps of greater interest to educationists, a demonstration lorry constructed to show films in broad daylight.

Books were shown not entirely for their own value but also as an opportunity to demonstrate how much more attractive a library can be if it is housed, not in the forbidding gloom so often encountered, but in well-lighted and comfortably furnished rooms. This library was combined with the information room, and it was a place which invited one not only to stay and browse but also to come back again and again. Elsewhere in the exhibition was a stand to display the type of material issued for use in information rooms, and another to show the standard unit library of four hundred volumes which has achieved throughout the Army a popularity which is no small tribute to the skill of those who contributed to the difficult task of its selection.

In the field the Royal Army Educational Corps was charged with the duty of producing regular news sheets during operations in order to keep men in touch with the news of home and of the battle-fronts. This was, however, only an operational expedient; the production of proper Army newspapers is the function of the Army Welfare Service whose work in this field was amply demonstrated by a display of no less than fifteen Army newspapers drawn from all quarters of the globe. But it is not enough that men should merely read the news, they must understand its impact on their own lives and on the lives of their fellows, and to ensure that this important need is met instruction in current affairs and citizen- ship is a compulsory part of every soldier's education. To assist them to undertake this work, officers and other instructors require up-to-date material, examples of which were tastefully set out on two stands. Here the visitor saw the original British Way and Purpose pamphlets produced during the War by the War Office and afterwards republished in a bound volume, and a selection of "Current Affairs" and "Map Review" produced fortnightly by the Bureau of Current Affairs, civilian heir to the war-time A.B.C.A.

The immediate and enduring success of "Map Review" during the War pointed the way to an extension of the principle to other subjects, and a collection of double-sided poster sheets was displayed to show how this has been done: art, design in everyday things, economic geography, everyday science, languages have all been successfully treated in a manner which is at once simple and striking, and, since the designing is done by the staff of the Directorate of Army Education, each sheet can be directly related to the appropriate syllabus of instruction or devised to meet some special need. Great interest was shown in the first of a new series of these visual aids which aims to illustrate talks to the men on countries overseas where they may be required to serve. This first one dealt with Gibraltar, showing simply but vividly the importance of its position and, on the reverse, a large-scale map surrounded by photographs in sufficient variety to give the soldier a picture of the sort of place he will find on arrival. Similar sheets on Malta (of which a printer's proof was shown), Burma, Malaya, Palestine and Germany are already in preparation, so that the young soldier need no longer harbour a sneaking fear of the unknown. This new series is but part of a comprehensive plan which will embrace films, film strips and pictorial exhibitions, each type having a distinct purpose and the whole scheme related to the teaching of geography and history in the plan for the general education of the soldier.

Examples of pictorial exhibitions were on view elsewhere : these consist of series of twelve to twentyfour panels mounted on stiff board, each panel suitably captioned. More than two hundred of these are already in circulation and they cover a wide range of subjects. Among those on view were "Plastics", "Handicrafts", "Your M.P.", and a very fine set illustrating the beautios of the properties of the National Trust. Analogous to the pictorial exhibition is the photo service which began during the War when there was a dearth of pictorial newspapers. Restricted now to overseas commands this service provides fortnightly 150 sets of a dozen photographs covering topics of general interest and aimed to keep men abreast of the times.

To a very wide range of musical gramophone records the Army has added recordings of extracts of the speeches of Allied statesmen as a means of giving dramatic effect to talks on the history of the War; language records for use with the War Office text-books on half a dozen languages; sets on teaching method; a series on the approach to poetry and another on oratory The B.B.C. also exhibited its contribution to Service education. The Forces Educational Broadcasts, first introduced as a part of the release period scheme of education, are still on the air and, although changed conditions have led to modifications in time and content, the B.B.C. continues to provide broadcasts of very high quality to assist service education, and the Army is now 
including instruction in the use of this new medium in training courses for its young instructors.

An unexpected feature at this exhibition was the Foreign Office show-piece, "Germany Under Control", which has recently toured the country to explain the work of the Control Commission. It has now been secured by the Director of Army Education to visit recruit training centres and give young soldiers an opportunity to learn why we are occupying Germany and how the country is being administered. Thus they will be able better to appreciate why their own services are required. Seen against the remainder of the Eltham Exhibition, this feature with its mass of detail formed a striking contrast to the studied simplicity of the material specially designed for teaching purposes, but the expert knowledge of its special staff of lecturers, the life-size models, the bronze eagle recovered from the Chancellery in Berlin and Hitler's personal flag should all appeal to the troops, who are noted for their insistence on the real thing.

The presence of a large number of distinguished guests, both military and civilian, at this demonstration of the Army's efforts to assist its teachers and enliven their teaching shows that there is a wide interest in the progress of educational method. Certainly the Army has proved that education need not be dull, and the continuous requests for visual material received at the War Office from ex-Service teachers now back in their classrooms would appear to prove that Service experience has convinced many teachers of the considerable value of visual education.

\section{FORTHCOMING EVENTS}

(Meeting marked with an asterisk * is open to the public)

\section{Tuesday, September 23}

TextILE Institute, LANCASHIRE SECTION (at $16 \mathrm{St}$. Mary's Parsonage, Manchester), at 7 p.m.-Miss A. G. Shaw : "Motion Study."

Tuesday, September 23-Thursday, September 25

FARADAY SOCIRTY (in the Physical Chemistry Laboratory, South Parks hoad, Oxford).--General Discussion on "The Labile Molecule".

Tuesday, September 23

At 2.30 p.m.

Wednesday, September 24

At 10 a.m. and 2.30 p.m.

Thursday, September 25

At 10 a.m.

Tuesday, September 23-Friday, September 26

Institution of NaVAL ARCHITECrs.-Autumn Meetings.

Tuesday, September 23-Wednesday, September 24

At the Municipal College, Portsmouth.

Thursday, September 25-Friday, September 26

At the Civic Centre, Southampton.

INSTrTdTe of METaLs (at the Institution of Engineers and Ship-

builders, 39 Elmbank Crescent, Glasgow). - Thirty-ninth Annual builders, 39 Elln
Autumn Meeting.

\section{Wednesday, September 24}

PhYSICAL SOCIETY (in the Physics Department of Imperial College, Imperial Institute Road, London, S.W.7) at 5.10 p.m.-Prof. E. Zernike: "Diffraction and Optical Image Formation" (The isth Thomas Young Oration).

LONDON SCHOOL OF HYGIENE AND TrROPICAL MEDICINE (at Keppel Street, Gower Street, London, W.C.1), at 2.30 p.m.-Discussion on "D.J.T. and the Aeroplane in the Control of the Tsetse Fly and Trypanosomiasis in South Africa". (A colour-sound fllm prepared and introduced by Dr. P. J. du Toit).*

Thursday, September 25-Friday, September 26

Imstitute of PHysics AND THE PHYsical Soctety in collaboration with the INSTITUTION OF ELECTRICAL ENGINEERS.-Jubilee of the Discovery of the Electron.

Thursday, September 25

At 7.30 p.m. (at Central Hall, Westminster, London, S.W.1). -
Thursday, September 25-Saturday, September 27

SOCTETY OF DYERS AND COLOURISTS (in the Albert Hall, Albert Road, Blackpool).-Symposium on "Recent Advances in the Theory and Practice of Dyeing".

Thursday, September 25

At 10.30 a.m. and 2 p.m.

Friday, September 26

At 10.30 a.m. and 2 p.m.

Saturday, September 27

At 10 a.m. and 2 p.m.

\section{Friday, September 26}

Society of PUBuic analysts and otger Axalytiont Chemists (joint meeting of the MICROCHKMISTRY GROOP and the PHYSIOAL METriods Group, at the University Chemical Laboratories, Cambridge) at 2 p.m.-Visits to the Collold Science Department and Radiochemistry Iaboratory ; at 4 p.m. (in the Chemistry Lecture Theatre Analysis".

Mandhrster Stamisticax Society, Indostrial Group (in the Lecture Room of the Society of Architects, 16 St. Mary's Parsonage. Deansgate, Manchester) at 6.45 p.m.-Mr. R. L. Plackett: "The Planning of Experiments in Industry".

Saturday, September 27

BIochemrcay SocreTY (at the School of Biochemistry, Tennis Court Road, Cambridge), at 11 a.m. - Scientiflc Papers.

\section{Sunday, September 28}

INSTITUTR OF ECONOMIO ENGINERRING (at the Waldorf Hotel, Aldwych, London, W.C.2), at 2.30 p.m.-Mr. J. Burgess : "Reflections on Productivity Assessment".

\section{APPOINTMENTS VACANT}

APPUICATroNs are invited for the following appointments on or before the dates mentioned :

LEOTURER IN BOTANY in the Department of Natural ScienceThe Principal, Technical College, Normanton Road, Derby (September 30).

VETERINARX INSPEOTORS (approximately 100 vacancies), RESEARCH TORS and ASSISTANT VETERINARY INVESTIQATION OFFICERS (approximately 40 vacancies)-The Secretary, Ministry of Agricultur Pentember 30).

lasgow Royal Infirmary Office, 135 Buchanan Street, Glasgow, C.1 Glasgow Royal

AsstStanT LifCTuRar IN Physics-The Secretary, St. Mary's AsstSTANT LECTURER IN PHYSICS-The Secretary, St. Mary
Hospital Medical School, Paddington, London, W.2 (October 1). JuNIOR ASSISTANT PHYSIOIST, for $\mathrm{X}$-ray and radium work at JUNIOR ASSISTANT PHYSTOIST, for X-ray and radium work at
Hammersmith and Lambeth Hospitals-The Medical Officer of Health (S.D.6), London County Council, County Hall, London, S.E.1 (October 1).

Crvir ENGINeERS for maintenance and development work in the Works Division of the Ministry of Finance-The Assistant Secretary (Establishments), Ministry of Finance, Stormont, Belfast (October 10). PRINCIPAL RESEAROH OFFIOER IN THE FUHL RESEAROH SECTION Australian Scientiftc Research Tiaison Office, Australia House, Strand, Australian Scientiftc Research tiaison
W.C.2, quoting No. 1345 (October 11)

W.C.2, quoting No. 1345 (October 11). DEPARTMENT OF ANATOMY-'The Registrar, The University, Sheffeld (October 11).

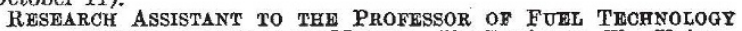
and an ASSISTANT LECTORER IN MINING-The Registrar, The University, Sheffleld (October 11)

PRINCIPAL SOIENTIFTC OFFICER, and a SCIENTIMO OFFICER FOR CHEMCAL Research Drvision, Ministry of Agriculture (N.I.)-The Assistant Secretary (Establishment), Ministry of Finance, Stormont, Belfast (October 15 )

LEOTURER IN SCIENCE (Biology), a LEOTURER IN CHEMISTRY, LECTURERS (4) IN PHYSICS, and LECTURRRS (2) IN MATHEMATTCS, at the Royal Military Academy, Sandhurst-Director of Studies, Royal Military Academy, Sandhurst, Camberley, Surrey (October 15). IEOTURER IN CHEMTSTRY-The Secretary, Northampton Polytechnic, St. John Street, Iondon, E.C.1 (October 18).

LEOTURER IN MATERMATICS at Makerere College, Hast AfricaThe Secretary, Inter-University Council for Higher Education in the Colonies, 8 Park Street, London, W.1 (October 18)

INSPECTORs (5) (Salmon and Freshwater Fisheries)-The Secretary, Ministry of Agriculture and Fisheries, 23-25 Soho Square, London, W.1 (October 18),

READERSHIP IN MORIID ANATOMY tenable at the Royal Free Hospital School of Medicine-The Academic Registrar, University of London, Senate House, London, W.C.I (October 23).

RMADERSHIP IN BrotoGr tenable at Guy's Hospital Medical SchoolThe Academic Registrar, University of London, Senate House, London, W.C.1 (October 28).

HEAD OF THE ENGINEERING DEPARTMENT-Principal and Clerk to the Governing Body, Wigan and District Mining and Technical College, Wigan.

LECTURER IN ChFMistry-The Principal, Technical College, Huddersfleld.

LECTURER IN MEChanicat ENGINGering SUBJECTS for Crewe Technical College-The Director of Education, County Education offices, (3/FHF), City Road, Chester.

LRO'TURLR to take CIVI AND MECHANICAI ENGINEERING SUBJROTS, with special reference to the Theory and Design of Structures, for the Technical College, Cardiff-The Director of Education, City Hiall, Cardiff. 